\title{
The Office of the Legal Counsel of the World Health Organization
}

\author{
by Gian Luca Burci and Claudia Nannini*
}

\section{Introduction}

WHO is one of the specialized agencies of the United Nations within the terms of Article 57 of the Charter and is the only global intergovernmental organization with a specific mandate in the field of public health. It was established pursuant to a decision of the International Health Conference, which met in New York from 19 June to 22 July 1946. ${ }^{1}$ The Constitution came into force on 7 April $1948^{2}$ - a day that has been celebrated ever since as the "World Health Day”.

At the time WHO was founded some organizations already existed at the global and regional levels with a mandate to facilitate cooperation on public health issues, in particular infectious disease control. At the global level, the Office International d'Hygiène Publique was established in 1907 with headquarters in Paris, followed by the creation of the Health Organization of the League of Nations in $1920 .^{3}$ At the regional

1 The summary report on proceedings minutes and final acts of the International Health Conference are reproduced in the Official Records of the World Health Organization No. 2 (New York, June 1948), available at http://apps.who.int/iris/bitstream/10665/85573/1/Official_record2_eng.pdf (last accessed 19 August 2015).

2 Constitution of the World Health Organization (New York, 22 July 1946), 14 UNTS 185. The WHO Constitution was subsequently amended by virtue of resolutions WHA26.37, WHA29.38, WHA39.6 and WHA51.23 adopted by the Twenty-sixth, Twenty-ninth, Thirtyninth and Fifty-first World Health Assemblies, with amendments entering into force on 3 February 1977, 20 January 1984, 11 July 1994 and 15 September 2005 respectively. The lastly amended version of the WHO Constitution is available in Basic Documents, $48^{\text {th }}$ ed. World Health Organization, 2014, 1-19.

3 For a description of the establishment and functioning of these organizations see WHO, The First Ten Years of the World Health Organization, 1958, pp. 15-27 (available at http://apps.who.int/iris/bitstream/10665/37089/14/a38153_eng_LR_part1.pdf, last accessed 12 February 2017).

\footnotetext{
* The author is a staff member of the World Health Organization. The author alone is responsible for the views expressed in this publication and they do not necessarily represent the decisions or policies of the World Health Organization.
} 
level, four councils had been established to oversee quarantine procedures in the Mediterranean area, while health issues in the Americas were specifically dealt with by the Pan American Sanitary Bureau, established in 1905 and later renamed Pan American Health Organization (PAHO). This proliferation of health institutions was also reflected at the normative level by the conclusion, between the second half of the $19^{\text {th }}$ century and the first half of the $20^{\text {th }}$ century, of a large network of international, regional and bilateral treaties dealing with infectious diseases and other public health risks, such as trade in narcotic drugs, occupational safety and transboundary air pollution. ${ }^{4}$

It became apparent in the first half of the $20^{\text {th }}$ century that this situation was no longer adequate to address the global nature of threats to public health. The need to unify action against the international spread of diseases and other public health problems through a single global institution, as well as the need to replace the existing patchwork of sanitary conventions and regulations with a single normative framework, led to the establishment of WHO and, consequently, the legal or functional integration of all preexisting regional entities into the Organization with the partial exception of PAHO (see infra section II).

\section{Legal and institutional context}

The paragraphs which follow will provide a brief description of the Organization's membership and governance structure, including special arrangements, and its mandate. ${ }^{5}$

4 See, for more details, D. P. Fidler, "The globalization of public health: the first 100 years of international health diplomacy”, Bulletin of the World Health Organization, 2001, 79: 842-849.

5 For a general overview of the WHO, see T.M Brown, M. Cueto, "The World Health Organization and the World of Global Health", in Routledge Handbook of Global Public Health (R. Parker, M. Sommer, eds, 2011), pp. 18-30; G. L. Burci, C.-H. Vignes, World Health Organization (Kluwer Law International, 2004). 


\section{Membership}

By allowing any State to become a Member of the Organization, the drafters of the Constitution set the basis for an organization open to universal membership. ${ }^{6}$ In particular, Member States of the United Nations may become members of the WHO by signing or otherwise accepting its Constitution in accordance with their constitutional processes, whereas other countries may be admitted as members when their application has been approved by a simple majority vote of the World Health Assembly. ${ }^{7}$ The Constitution does not contain any provisions on withdrawal from membership or expulsion. However, Members can see their voting privileges and services suspended by the Health Assembly as a result of the failure to meet their financial obligations to the Organization or in other exceptional circumstances. ${ }^{8}$ The Constitution provides for a further peculiar form of involvement in the work of the Organization in favor of those territories which are not responsible for the conduct of their international relations. Such territories may be admitted as Associate Members upon application made on their behalf by the Member or other authority responsible for their international relations. ${ }^{9}$ At the regional level, even territories and groups of territories which are not Associate Members may participate in the work of regional committees under certain conditions. ${ }^{10}$

6 Article 3 of the Constitution. As of August 2015, the Organization counts 194 Member States, one more than the United Nations (information available at http://who.int/countries/en/, last accessed 12 February 2017 ).

7 Articles 4 to 6 of the Constitution.

8 Article 7 of the Constitution.

9 There are currently only two Associate Members - Puerto Rico and Tokelau.

10 WHO, Resolution WHA2.103 Rights and Obligations of Associate Members and Other Territories, operative paragraph 4. Prior consultation between the States Members in the region and the Members or other authority having responsibility for the international relations of these territories is needed. On this basis, Macao, Hong Kong and New Caledonia participate in the WHO Regional Committee of the Western Pacific Region in their own name. 
Sessions of the governing bodies may be attended, in addition to representatives of Member States and Associate Members, by representatives of intergovernmental and non-governmental organizations. ${ }^{11}$ Furthermore, a standing invitation to attend sessions of the Assembly, in an observer capacity, has been extended by the Health Assembly to representatives of Palestine since $1974 .{ }^{12}$ Invitations are also regularly issued under the sole authority of the Director-General to a number of entities active at the international level such as the Holy See, the Order of Malta, the International Committee of the Red Cross, the International Federation of Red Cross and Red Crescent Societies and the Global Fund to Combat AIDS, Malaria and Tuberculosis.

\section{Governance structure}

The World Health Assembly, the Executive Board and the Secretariat are the organs of the Organization under the terms of Article 9 of the Constitution. The Health Assembly is the supreme decision-making body of the Organization. It meets in regular annual sessions - usually in Geneva, in May - and in special sessions as may be necessary. The Constitution assigns to the Health Assembly thirteen functions, including the determination of the policies of the Organization, the appointment of the Director-

11 Rule 3 of the Rules of Procedure of the Health Assembly ; Rule 4 of the Rules of Procedure of the Executive Board. In accordance with the Framework of Engagement with Non-State Actors, participation is also be open to other entities in official relations with the Organization (see Annex to Resolution WHA69.10, paragraph 50).

12 WHO, Resolution WHA27.37 Activities of the World Health Organization with regard to assistance to liberation movements in southern Africa pursuant to United Nations General Assembly resolution 2918 (XXVII) and Economic and Social Council resolution 1804 (LV), in which the Health Assembly requested the Director-General "to take the necessary steps to invite the representatives of the national liberation movements recognized by the Organization of African Unity or by the League of Arab States to attend the meetings of WHO in an observer capacity.”. In May 2000, the World Health Assembly adopted resolution WHA53.13 on Collaboration within the United Nations system and with other intergovernmental organizations, in which it decided to confer upon Palestine in the World Health Assembly and other meetings of the World Health Organization, in its capacity as an observer, the rights and privileges described in United Nations General Assembly resolution 52/250 of 7 July 1998 concerning participation of Palestine in the work of the United Nations. 
General, the supervision of the financial policies, the review and approval of the budget, as well as the adoption of the normative instruments of WHO, namely, conventions, regulations and recommendations. ${ }^{13}$

The Executive Board is composed of thirty-four persons whose designation follows a complex procedure set out in Article 24 of the Constitution and in the Rules of Procedure of the Health Assembly. Members entitled to designate a person to serve on the Board are elected by the Health Assembly following an unwritten but consistent pattern of regional representation proportional to the number of states per region. Each of these Members then appoints to the Board a person technically qualified in the field of health, who may be accompanied by alternates and advisers. It is worth noting that members of the Board were originally meant to serve in their personal capacity but, in practice, this principle was not respected over the years. This ambiguity was eventually resolved through a resolution of the Health Assembly, which interpreted the relevant constitutional provision in light of the established practice, thus clarifying that members of the Board are to be considered as governments' representatives. ${ }^{14}$ The Board meets at least twice a year, in January and in May immediately after the Health Assembly, and is responsible under Article 28 of the Constitution, inter alia, for giving effect to the decisions and policies of the Health Assembly and acting as the executive organ of the Health Assembly. ${ }^{15}$ Notwithstanding the constitutional design of its functions, the Board has increasingly limited itself to performing preparatory functions for the Health Assembly, by reviewing agenda items and proposing draft resolutions that will be considered by the latter at a subsequent session, rather than executing in detail the policies adopted by the Assembly. A recent deviation from this practice has occurred in relation to the 2014-2015 Ebola outbreak in Western Africa. At its third special session in January 2015, the Board

13 Article 18 of the Constitution.

14 WHO, Resolution WHA51.26 Review of the Constitution and regional arrangements of the World Health Organization: status of members of the Executive Board: clarification of the interpretation of article 24 of the WHO Constitution.

15 Article 28 of the Constitution. 
exercised for the first time its emergency powers under Article 28(i) of the Constitution and adopted policy decisions which have proved to be crucial in ending the outbreak, strengthening global preparedness and improving WHO's capacity to prepare for and respond to future large-scale outbreaks and emergencies with health consequences. ${ }^{16}$

Finally, the Secretariat is made up of the Director-General as well as the technical and administrative staff of the Organization. The Director-General is the chief technical and administrative officer of the Organization as a whole, albeit subject to the authority of the Board, and is appointed by the Health Assembly on the nomination of the Board for a term of five years, renewable once. The overall process for the election of the Director-General has been revised several times since the late 1990s. The most recent innovations introduced in 2012-2013 consist of a Code of Conduct applicable throughout the election process, the nomination by the Executive Board of up to three candidates instead of one as in the past, and the possibility for Member States and candidates to interact in the framework of electronic and live forums ahead of the Board's nominations. $^{17}$

Regionalization is one of the distinctive features of WHO. While its headquarters are located in Geneva, the Organization is articulated around six regions - Africa, the Americas, South-East Asia, Europe, Eastern Mediterranean and Western Pacific - with a corresponding number of regional organizations. ${ }^{18}$ All regional organizations were established by the Health Assembly "to meet the special needs of such area[s]" in accordance with Article 44(b) of the Constitution. ${ }^{19}$ Each regional organization consists

16 WHO, Resolution EBSS3.R1 Ebola: ending the current outbreak, strengthening global preparedness and ensuring WHO's capacity to prepare for and respond to future large-scale outbreaks and emergencies with health consequences.

17 A more detailed description of the current process for the election of the Director-General can be found in document A67/51. Relevant documents and information are accessible at: http://apps.who.int/gb/ep/ (last accessed 27 August 2016).

18 Article 44 of the Constitution.

19 The six regional organizations were established between 1949 and 1952, after the Health Assembly delineated the six geographical areas of the Organization. Regional Offices are 
of a regional committee, composed of representatives of the Members, Associate Members and other territories in the region concerned, and a regional office, led by a Regional Director who serves as the administrative organ of the regional committee and the head of the regional office. Regional Directors are appointed by the Executive Board upon the nomination of the regional committee concerned and exercise broad programmatic and administrative functions pursuant to the delegation of authority granted to them by the Director-General. The fact of being elected rather than appointed officials gives Regional Directors a strong connection with the countries of their respective regions and has historically led to a high level of autonomy of regional offices vis-à-vis the central role played by the Director-General and WHO's Headquarters. If WHO can then be rightly considered a decentralized organization, it should equally be noted that each regional organization is an integral part of the Organization as expressly stated in Article 45 and implicitly confirmed in other provisions of the Constitution. ${ }^{20}$ Consistent with the decentralized nature of the Organization, 149 country offices $^{21}$, some of which provide support to more than one country, territory or area, play a key role in the implementation of technical cooperation activities with relevant national authorities and partners.

A special aspect of the regional structure of WHO is the relationship between the latter and PAHO. While the preexisting Pan-Arab Regional Health Bureau merged into WHO, thereby becoming its regional organization for the Eastern Mediterranean, WHO

currently located in Brazzaville, Republic of the Congo (African Region), Washington D.C., United States of America (Region of the Americas), Copenhagen, Denmark (European Region), Cairo, Egypt (Eastern Mediterranean Region), New Delhi, India (South-East Asia Region) and Manila, the Philippines (Western Pacific Region).

20 In particular, Article 51 of the Constitution, which confers on the Director-General authority over the regional office, and those provisions (Articles 18, 19, 21, 28 and 29 of the Constitution) which imply the general supervision and control of the Health Assembly and the Executive Board over all activities of the Organization.

${ }^{21}$ See document EB140/INF./2 on WHO presence in countries, territories and areas : 2015 report. The updated report on WHO presence in countries, territories and areas will be presented to the Seventieth World Health Assembly in May 2017. 
and PAHO concluded an agreement on 22 April 1949 under whose terms the Pan American Sanitary Conference, through the Directing Council and the Pan American Sanitary Bureau, serve respectively as the Regional Committee and the Regional Office of WHO for the Americas. ${ }^{22}$ PAHO therefore enjoys a special status within WHO. It is a separate international organization with its own Constitution, legal personality, governance structure, budget, staff and rules, while at the same time serving as the regional organization of WHO for the Americas and as such acting as an organ of the Organization. The 1949 Agreement provides the legal basis for the relationship between WHO and PAHO in this respect and establishes a unique relationship at least within the UN system. The Agreement contains a compatibility clause between, on one hand, the health and sanitary conventions and programs adopted and promoted by PAHO and, on the other hand, the policy and programs of WHO. ${ }^{23}$ The organic links between the two organizations are strengthened by the fact that PAHO's Director also serves as Regional Director of WHO for the Americas, and that a portion of PAHO's expenses are financed from the budget of WHO to reflect its functions as WHO's regional organization. Although practice has led to a high level of functional integration between the two organizations, some WHO policies and rules are not applicable to PAHO as a separate organization, thus triggering a number of legal and administrative issues.

Finally, mention should be made of the International Agency on Research in Cancer (IARC), a semi-autonomous institution established in 1965 through a resolution of the World Health Assembly that adopted its statute. ${ }^{24}$ IARC has a separate membership, ${ }^{25}$ budget and governance structure, including a Governing Council

22 See Article 2 of the Agreement between the World Health Organization and the Pan American Health Organization, approved by the Second World Health Assembly on 30 June 1949 in resolution WHA2.91 (also reproduced in Basic Documents, $48^{\text {th }}$ ed. World Health Organization, 2014, 41-43).

${ }^{23}$ Ibidem, Article 3.

24 WHO, Resolution WHA18.44 Establishment of an International Agency for Research on Cancer.

${ }^{25}$ As of August 2016, the Agency counts 25 Participating States. 
composed of representatives of Participating States and the WHO Director-General, which directs its general policy. IARC's Director is nominated by the Governing Council and appointed by the Director-General. IARC thus shares the features of a WHO programme with those of a separate international organization. As part of its mission, IARC performs primary research in its laboratories and publishes a wide range of series, handbooks, textbooks, and manuals, thereby greatly contributing to the standard-setting activity of the Organization in the field of cancer.

\section{Special arrangements}

A faithful presentation of WHO would not be complete without mentioning the several United Nations joint inter-agency programs in which the Organization participates, such as the United Nations program on HIV/AIDS (UNAIDS). UNAIDS is a joint inter-agency program, established in the mid-1990s as a response to the gravity and complexity of the growing HIV/AIDS pandemic. It was formally established by a resolution of the UN Economic and Social Council and a memorandum of understanding signed by the initial six cosponsors, i.e. UNICEF, UNDP, UNFPA, WHO, UNESCO, and the World Bank. ${ }^{26}$ At the global level, its structure consists of the Program Coordinating Board, the decision-making organ of the Program which included for the first time five nongovernmental organizations with almost full rights of participation; a Committee of Co-sponsoring Organizations which serves as the standing committee of the Program Coordinating Board; and a Secretariat located in Geneva, headed by an Executive Director appointed by the United Nations Secretary General upon the proposal of the cosponsoring organizations. At the country level, UNAIDS operates through United Nations

UN Document, Resolution 1994/24 on Joint and co-sponsored United Nations programme on human immunodeficiency virus/acquired immunodeficiency syndrome (HIV/UNAIDS); Memorandum of Understanding on the Joint and Co-sponsored United Nations Programme on Human Immunodeficiency Virus/Acquired Immunodeficiency Syndrome, reproduced in the Appendix to UN Document E/1996/42 (7 May 1996). 
thematic groups on HIV/AIDS composed of local representatives of the co-sponsoring organizations. Under the memorandum of understanding, WHO is responsible for the administration in support of the Programme, which is subject to the financial, administrative and staff regulations, rules and procedure of WHO adjusted, if necessary, to take into account the special needs of the Programme.

Cosponsored programmes are integral to core WHO activities and are part of the WHO programmatic accountability framework but are financially and/or programmatically cosponsored by a number of other UN agencies. In addition to UNAIDS, cosponsored programmes include the Special Programme on Research and Training in Tropical Diseases (TDR) ${ }^{27}$ and the Special Programme of Research, Development Research and Training in Human Reproduction (HRP). ${ }^{28}$

WHO extensively collaborates with global health partnerships and other initiatives. Public-private partnerships (PPPs) are a peculiar form of collaborative arrangements that usually involve public and private partners, including private not-forprofit entities such as philanthropic foundations, as well as, occasionally, for-profit entities, in the pursuit of specific health goals, e.g. the development of new medicines or vaccines or the mobilization of financial resources to address urgent health problems. ${ }^{29}$

27 The Special Programme on Research and Training in Tropical Diseases is a global programme of international technical cooperation initiated by WHO and co-sponsored by UNICEF, UNDP, and the World Bank. It was established in 1978 on the basis of a memorandum of understanding concluded amongst the co-sponsors. The text of the memorandum is available at : http://www.who.int/tdr/documents/MOU-2013-rev1-en.pdf?ua=1 (last accessed 12 February 2017).

28 The Special Programme of Research, Development Research and Training in Human Reproduction is a global programme of international technical cooperation initiated by WHO to promote, coordinate, support, conduct and evaluate research in human reproduction, and cosponsored by UNDP, UNFPA and the World Bank on the basis of a memorandum of understanding concluded in 1988 and revised in 2012 . Bboth texts are available at : http://www.who.int/reproductivehealth/about_us/hrp/governance/en/ (last accessed 12 February 2017).

29 On PPPs in the field of health see L. C. Clarke, "Responsibility of International Organizations under International Law for the Acts of Global Health Public-Private Partnerships”, Chicago Journal of International Law, 2011, vol. 12, 55-84 and G.L. Burci, "Public/Private 
Some of them are legally incorporated entities external to WHO whilst others are unincorporated entities hosted by WHO. WHO currently hosts four public-private partnership of the latter kind. ${ }^{30}$ Although WHO-hosted partnerships derive their legal personality from WHO and are subject to the Organization's Rules and Regulations, they have their own governance structures and accountability frameworks, separate from those of the Organization. The role played by WHO vis-à-vis hosted partnerships is twofold in that, on the one hand, it provides institutional support in its capacity as hosting entity while, on the other hand, it is a full member of their respective governance structures and as such participates in their decision-making. ${ }^{31}$ The unusual features of partnerships have at times raised delicate legal problems, in particular due to the tensions between the independence of their governance from WHO and the latter's ultimate liability for their actions.

The Organization has furthermore established a number of networks and alliances to assist it in the implementation of its programmatic activities, which have no formal governance structure and are mainly led and managed by the Secretariat. For example, the International Food Safety Authorities Network (INFOSAN) is a global network of national food safety authorities, managed jointly by FAO and WHO, through which the Organizations assists Member States in managing and communicating food safety risks. ${ }^{32}$ The UN Road Safety Collaboration, set up in 2004 in response to a decision by the UN

Partnerships in the Public Health Sector”, International Organization Law Review, 2009, vol. 6, pp. 359-382.

30 These are the International Drug Purchase Facility (UNITAID), the Partnership for Maternal, Newborn and Child Health, the Alliance for Health Policy and Systems Research, and the Global Health Workforce Alliance. WHO's engagement with global health partnerships and hosting arrangements is governed by a dedicated policy endorsed by the Sixty-third World Health Assembly in resolution WHA63.10.

31 WHO indeed sits on the Executive Board of UNITAID, and on the Board of the Partnership for Maternal, Newborn and Child Health, the Alliance for Health Policy and Systems Research and Global Health Workforce Alliance.

32 More information on INFOSAN can be found at : http://www.who.int/foodsafety/areas_work/infosan/en/ (last accessed 27 August 2016). 
General Assembly, is another example of an informal consultative mechanism, in this case to discuss global road safety issues with a view to facilitating international cooperation and strengthening coordination among UN agencies and international partners in this area. ${ }^{33}$

\section{Mandate}

The objective of the Organization, as stated in Article 1 of the Constitution, is "the attainment by all peoples of the highest possible level of health", which is in turn recognized in the Preamble as "one of the fundamental rights of every human being without distinction of race, religion, political belief, economic or social condition”, "fundamental to the attainment of peace and security", and "dependent upon the fullest cooperation of individuals and States". To achieve this objective, the Organization has been assigned several functions, which can be broadly categorized as direction and coordination of international health work, normative activities, support to research and provision of technical cooperation to member states. ${ }^{34}$

Thanks to the broad scope of its mandate, the Organization has adapted to a constantly changing environment through a significant evolution and expansion of its programmes and activities over the years. ${ }^{35}$ The first years of the Organization's life have been characterized by campaigns to control and eradicate specific diseases such as

33 More information on the UN Road Safety Collaboration can be found at :http://www.who.int/roadsafety/en/ (last accessed 27 August 2016).

34 This categorization has been proposed by G. L. Burci and C.-H. Vignes, World Health Organization, 2004, Kluwer Law International. The Organization's functions are listed in Article 2 of the Constitution.

35 For a general overview of health trends over the $20^{\text {th }}$ century and the health agenda for the $21^{\text {st }}$ century see The World Health Report 1998 - Life in the $21^{\text {st }}$ century: A Vision for All (WHO, Geneva, 1998), which was published on the occasion of WHO's $50^{\text {th }}$ anniversary (available at http://www.who.int/whr/1998/en/whr98_en.pdf?ua=1, last accessed 20 August 2015).WHO's achievements and future tasks are also explored in C. Clift, The Role of the World Health Organization in the International System, London: Chatham House, 2013. 
malaria and smallpox, which have traditionally been financed through voluntary funds. ${ }^{36}$ While vertical programmes of this kind still continue to be implemented, WHO's approach has undergone a certain reorientation starting from the 1970s with the launching of more "horizontal programmes”37 addressing policy and structural considerations, such as primary health care, health system strengthening, health workforce and the promotion of universal health coverage. This dichotomy should in part be reconsidered in light of the recently created Health Emergencies Programme. The new Programme, which follows the aforementioned decision by the Executive Board's special session in January 2015 in response to the Ebola virus outbreak in West Africa, puts an emphasis on WHO's operational functions and, more specifically, the provision of support in the management of health emergency risks at the country level, as well as the leadership and coordination of the international health response. ${ }^{38}$

Among the many functions assigned to WHO, normative functions certainly play a central role. The Constitution mandates the Organization, inter alia, "to propose conventions, agreements and regulations, and make recommendations with respect to international health matters", "to establish and revise as necessary international nomenclatures of diseases, of causes of death and of public health practices", and "to develop, establish and promote international standards with respect to food, biological, pharmaceutical and similar products.”. ${ }^{39}$ Articles 19 to 23 of the Constitution further

36 C. Clift, supra, pp. 23-24.

37 It has been argued that this has mainly been the result of the focus put on the concept of "health for all", which was embraced by the "Global Strategy for Health by All by the Year 2000 », adopted by the Health Assembly in 1981 (C. Clift, supra, pp. 26).

38 In May 2016, the Health Assemby welcomed "progress made in the development of the new Health Emergencies Programme" as well as the elaboration of an implementation plan and timeline for the new Programme (decision WHA69(9) Reform of WHO's work in health emergency management: WHO Health Emergencies Programme). More information can be found in document A69/30 and at http://who.int/about/who_reform/emergency-capacities/en/ (last accessed 19 September 2016).

39 Article 2(k), (s) and (u) of the Constitution. 
elaborate on the Health Assembly's authority to adopt legally binding instruments, i.e. conventions and agreements on any health related matter, regulations in five specific areas, and soft law instruments in the form of recommendations. Hard law instruments have been scarce, with only one international convention and two regulations adopted so far. The WHO Framework Convention on Tobacco Control (WHO FCTC), which was adopted on 21 May 2003 and entered into force on 27 February 2005, aims at addressing some of the root causes of the tobacco epidemic and tackling the health consequences of tobacco use. ${ }^{40}$ The Conference of the Parties to the Convention at its fifth session also adopted a Protocol to Eliminate Illicit Trade in Tobacco Products, which has however not yet entered into force. ${ }^{41}$ The Health Assembly has so far adopted two sets of regulations under Article 21(a) and 21(b) of the Constitution, respectively. Firstly, the International Health Regulations, as revised most recently in 2005 (IHR), is an international legal instrument binding on 196 countries across the globe, including all the Member States of WHO. ${ }^{42}$ The IHR establish a legal framework for the prevention and control of the

40 WHO, Resolution WHA56.1 WHO Framework Convention on Tobacco Control. As of September 2016, the Convention counts 180 Parties (information available at http://www.who.int/fctc/signatories_parties/en/, last accessed 22 September 2016).

41 Conference of the Parties to the WHO Framework Convention on Tobacco Control, Decision FCTC/COP5(1) Protocol to Eliminate Illici Trade in Tobacco Products. Amongst the literature on these instruments, see J. Liberman, "The new WHO FCTC Protocol to Eliminate Illicit Trade in Tobacco Products- challenges ahead”, ASIL Insights, 2012, vol. 16; J. Collin, K. Lee, K. Bissell, "The Framework Convention on Tobacco Control: the Politics of Global Health Governance”, in Global Health (Ashgate, 2009), 265-282;N. Devillier, "La convention-cadre pour la lutte anti-tabac de l'Organisation mondiale de la Santé”, Revue belge de droit international, 2005, vol. 38, 701-728; G. L. Burci, "La convention-cadre de l'OMS pour la lutte antitabac”, Revue générale de droit international public, 2005, 79-84.

42 International Health Regulations (2005), $2^{\text {nd }}$ ed. (World Health Organization, 2008). The revised International Health Regulations (2005) were adopted by the Fifty-eighth World Health Assembly in resolution WHA58.3. Amongst the extensive literature on this subject, see R. S. Katz, A. Muldoon, "Negotiating the Revised International Health Regulations (IHR)", in Negotiating and navigating global health : case studies in global health diplomacy (World Scientific, 2011), 77-99; D. P. Fidler, L. O. Gostin, "The New International Health Regulations: an Historic Development of International Law and Public Health", in Global Health (Ashgate, 2009), 489-498; D. Fidler, "From International Sanitary Conventions to Global Health Security: the New International Health Regulations”, Chinese Journal of International Law, 2005, vol. 4, 325-392. 
international spread of disease, based on a cooperative approach between States Parties and WHO and extensive directive powers delegated to the Director-General. Secondly, the Nomenclature Regulations ${ }^{43}$, adopted in 1956 and revised in 1967, require countries to compile mortality and morbidity statistics in accordance with the latest applicable revision of the International Statistical Classification of Diseases, Injuries and Causes of Death (ICD) as adopted from time to time by the World Health Assembly. The Nomenclature Regulations therefore assign binding force to the ICD as periodically revised. ${ }^{44}$ Much higher is the number of non-legally binding standards. It should be noted that while Article 23 empowers the Health Assembly to adopt regulatory recommendations in the field of health, only a few instruments have been explicitly placed under this provision. A notable example of this kind is the Pandemic Influenza Preparedness Framework (PIP Framework), an innovative public health instrument adopted by the Health Assembly in 2011 to better prepare the world to respond to pandemic influenza. ${ }^{45}$ In addition, a significant number of standards and recommendations have been developed by the Secretariat on a grant of authority by a governing body, but not approved individually by the latter. An example of this kind is the WHO Model List of Essential Medicines, which was first developed by the Secretariat at the request of the Twenty-eighth World Health Assembly ${ }^{46}$ and then revised

43 WHO doc, Resolution WHA20.18 WHO Nomenclature Regulations. The Nomenclature Regulations of 1967 follow the "WHO Regulations n. 1 regarding nomenclatures with respect to disease and causes of death” adopted in 1948, amended in 1956 and then subject to complete review in 1966 and 1967.

44 The most recent version of the ICD was endorsed by the Health Assembly in resolution WHA43.24 of 1990.

45 WHO, Resolution WHA64.5 Pandemic influenza preparedness: sharing of influenza viruses and access to vaccines and other benefits. On the negotiations of this instrument see S. Vezzani, "Preliminary Remarks on the Envisaged World Health Organization Pandemic Influenza Preparedness Framework for the Sharing of Viruses and Access to Vaccines and Other Benefits”, The Journal of World Intellectual Property, 2010, vol. 13, 675-696.

46 WHO, Resolution WHA28.66 Prophylactic and therapeutic substances. 
every two years upon the recommendation of the Expert Committee on the Selection and Use of Essential Medicines. In other cases, instead, standards are developed by the Secretariat, supported by experts, and published by the Organization without having been specifically requested or endorsed by the governing bodies. This applies, in particular, to the many technical guidelines that the Organization issues every year in accordance with the qualitative standards set out in the WHO Handbook for Guideline Development ${ }^{47}$.

\section{The Office of the Legal Counsel}

The following paragraphs will provide an overview of the functions and internal structure of the Office of the Legal Counsel, the applicable law and the Office's role in the development of international law.

\section{Functions}

The overall objective of the Office of the Legal Counsel ("the Office") is the protection of the legal interests of the Organization through the provision of a wide spectrum of advice, services and assistance on legal matters affecting the operation and activities of WHO. As the centralized legal service of the Organization, it provides legal advice and services to the Director-General, Secretariat units and offices at headquarters, regional and country levels, as well as to WHO's governing bodies. It is complemented in its work by a small number of specialized lawyers working in other departments, including those dealing with human resources, intellectual property rights, the PIP Framework, the WHO FCTC and the IHR. Although the Office serves the Organization as a whole and there are no decentralized legal services in most regional offices, a significant exception is represented by the WHO Region of the Americas, which benefits from the legal services provided by the Legal Office of PAHO in its capacity as a separate

47 WHO Handbook for Guideline Development, $2^{\text {nd }}$ edition, 2014, available at http://www.who.int/kms/handbook_2nd_ed.pdf (last accessed 23 September 2016). 
international organization. The two offices act in a collaborative manner and regularly consult with a view to ensuring consistency in their approach.

The functions performed by the Office can be roughly categorized as negotiation functions, advisory functions, external representation, and institutional integrity-related functions.

\section{i) Negotiation functions}

The Office is closely involved in the negotiation of legal instruments, agreements and arrangements that provide the normative framework for the Organization's activities and interaction with its Member States, intergovernmental organizations and non-state actors. In addition to the negotiation of various types of commercial agreements and contracts, the Office is involved in the negotiation of so-called "Basic Agreements" which establish the normative framework for WHO's bilateral technical cooperation with its Member States. Basic Agreements stipulate priority areas of cooperation and set forth the general principles applicable to the execution of technical cooperation programs as well as the respective administrative and financial obligations of the government concerned and WHO, and usually include provisions on the granting of exemptions, privileges and immunities to the Organization and its staff. The respect for the privileges and immunities of the Organization, its staff and assets in regional and country offices is of crucial importance given the risks involved in WHO's field activities. The level of respect and the cooperation of local governments in asserting privileges and immunities is, however, inconsistent; the Office regularly finds itself forced to make representations with the governments concerned and remind them of their obligations under the relevant legal instruments. This has to be done sometimes in urgent and dramatic circumstances such as when WHO staff are arrested or subject to enforcement measures. Mention should also be made of "Host-country Agreements", which regulate WHO's status and activities in countries hosting WHO's headquarters, regional offices and out-posted 
offices $^{48}$, as well as meetings of the WHO governing bodies when they are held outside WHO's offices (such as the annual regular meetings of the Regional Committees), or meetings otherwise convened under the auspices of WHO (such as the biennial session of the Conference of the Parties to the WHO FCTC).

\section{ii) Advisory functions}

A second category of functions, which represent the largest proportion of the Office's workload, consists of the provision of legal advice and support both during sessions of the governing bodies, intergovernmental meetings and other similar processes as well as to support their preparation and follow-up; and, at the request of the Secretariat at the global, regional and country levels. Advice is usually provided on a confidential basis and is therefore not publicly available. As an exception to this principle, legal opinions on specific issues may be reflected into publicly available governing body documents $^{49}$ and, if provided by the Legal Counsel during governing body meetings of a public nature, are reflected in the summary records or reports of such meetings. On a general basis, technical units and senior management are not obliged to seek advice on the activities or decision-making processes they are involved in. In other words, legal advice is usually provided upon request and, once provided, the unit who requested it enjoys discretion in deciding whether and to what extent to follow it. Of course, should the unit concerned neglect to seek legal advice or choose not to follow the advice

48 Outposted offices may serve as liaison offices (such as the WHO Office at the European Union based in Brussels, Belgium), to provide administrative support (such as the Global Service Centre based in Kuala Lumpur, Malaysia) or to provide technical support on specific health matters (such as the WHO Centre for Health Development based in Kobe, Japan).

49 For example, the advice concerning the duration of temporary recommendations under Article 15(3) of the IHR, contained in document A68/21/Add.3 on Poliomyelitis: Temporary recommendations regarding the international spread of wild poliovirus: considerations concerning their continuation in light of Article 15.3 of the International Health Regulations (2005). 
received, it may be considered in breach of its duty of care and due diligence in case its actions engage the responsibility of the Organization.

There are cases, however, where statutory legal advice must be sought and followed, in accordance with internal policies of the Organization, in particular with respect to the production of maps intended for WHO materials whenever such maps depart from pre-approved templates, or situations that may trigger the application of enforcement measures enacted by the UN Security Council against States which are also WHO Member States. The Office is also represented in the Contracts Review Committee, a standing body responsible for ensuring that contracts are concluded by the Organization in its best interest and in accordance with applicable rules and regulations. In any case, consultations with the technical units concerned are undertaken on a regular basis to clarify technical aspects of legal issues, as appropriate, and to strive to address legal issues informally and at an early stage of the decision-making process.

Advice is given on a wide range of matters, both of a procedural and substantive nature and it is impossible to summarize their scope and range here. Procedural questions typically relate to the interpretation and application of the terms of reference and rules of procedure of the governing bodies, other applicable texts, and the established practice of the Organization, at all stages of the governing body sessions cycle. Legal advice may be sought, for instance, in relation to the development of the provisional agenda of the governing body sessions, Member States' credentials, the text and /or the consideration of draft resolutions and decisions, the conduct of elections and voting procedures.

A large amount of work arises in connection with the implementation of WHO's normative instruments. With regard to the WHO FCTC, for example, not only did the Office participate and provide constant assistance during the negotiation and drafting phases that led to the adoption of this convention and later of its Protocol to Eliminate Illicit Trade in Tobacco Products, but it also regularly provides legal advice and guidance to the Convention's Conference of the Parties and Secretariat on a wide spectrum of issues. As to the IHR, legal officers regularly provide advice and support in advance, during and in follow-up to meetings of the Emergency and Review Committees convened 
under Articles 48 and 50 of the IHR, respectively, and support other activities with legal or institutional implications for WHO related to the implementation of this instrument. A notable example is the monitoring by WHO, under Article 43 of the IHR, of national disease control measures that may interfere with international traffic and trade.

Special mention should be made of the important contribution given by the Office to the response to the 2014-2016 Ebola virus disease outbreak. In addition to carrying out its ordinary tasks, the Office was actively involved in identifying legal issues and exploring possible solutions in an exceptional crisis situation, for example with regard to the deployment of foreign medical teams and the arrangement of medical evacuation by air of the staff of WHO and other partners. The Office provided substantial input and support to the Ebola Interim Assessment Panel and the IHR Review Committee convened by the Director-General to review WHO's role and the performance of the IHR in the response to the Ebola outbreak and to make recommendations for their improvement.

\section{iii) External representation}

The Office represents the Organization externally at meetings and conferences of a legal nature, as well as in judicial or arbitral proceedings in which the Organization is involved. Although contractual or tort litigation or arbitration are very rare, the Office regularly represents the Organization before the Administrative Tribunal of the International Labour Organization in relation to complaints brought by serving and former officials of the Organization with regard to their conditions of service. WHO, at least during the last three decades, has not been subject to claims by states or other international organizations alleging breaches of rules of international law. The Office has consequently not been involved in arbitration or other forms of international adjudication or settlement.

The Organization has used the authority granted by Article 96(2) of the Charter of the United Nations to request advisory opinions from the International Court of Justice on legal questions arising within the scope of its activities. The Legal Counsel represented 
the Organization before the International Court of Justice in the context of two advisory proceedings, the first relating to the Interpretation of the Agreement of 25 March 1951 between the WHO and Egypt ${ }^{50}$ and the second concerning the Legality of the Use by a State of Nuclear Weapons in Armed Conflict. ${ }^{51}$

A recent development has been the submission of amicus curiae briefs in the context of judicial proceedings that directly touch on health-related matters and, specifically, the interpretation and application of WHO's normative instruments. The Office participated in drafting two amicus curiae briefs in the framework of international proceedings against, respectively, Uruguay and Australia in relation to domestic regulations that affected the labelling and brand marketing of tobacco products. ${ }^{52}$ WHO's interventions in those proceedings is an exception to its long-standing policy not to get involved in national or international judicial or similar proceedings in order to preserve its impartiality and independence as an international organization at the service of its

50 Interpretation of the Agreement of 25 March 1951 between the WHO and Egypt, Advisory Opinion, I. C.J. Reports 1980, p. 73. On that occasion the Court set forth the principles and rules concerning consultation, negotiation and notice that would have applied between the WHO and Egypt, had the WHO Regional Office for the Eastern Mediterranean been transferred from the Egyptian territory.

51 Legality of the Use by a State of Nuclear Weapons in Armed Conflict, Advisory Opinion, I. C. J. Reports 1996, p. 66. The Court reasoned that the request at stake was not related to the effects of the use of nuclear weapons on health, but rather to the legality of the use of such weapons in view of their health and environmental effects. In light of this circumstance, it concluded that the request did not relate to a question which arose within the scope of the activities of the World Health Organization and that, for this reason, it lacked jurisdiction to give the advisory opinion requested. On the WHO request specifically, see M. Bothe, "The WHO Request", in International Law, the International Court of Justice and Nuclear Weapons (L. Boisson de Chazournes, P. Sands, eds, 1999), pp.103-111.

52 Cfr. Philip Morris Brand Sàrl, Philip Morris Products S.A. and Abal Hermanos S.A. v. Oriental Republic of Uruguay, Award, 8 July 2016, (ICSID Case No. ARB/10/7), available at : https://icsid.worldbank.org/ICSID/FrontServlet?requestType=CasesRH\&actionVal=showDoc \&docId=DC9012_En\&caseId=C1000 . Philip Morris Asia Limited (Hong Kong) v. The Commonwealth of Australia (Case number 2012-12),. All publicly available procedural orders issued by the arbitral tribunal can be obtained from the Permanent Court of Arbitration website http://www.pcacases.com/web/view/5).. 
member states. The Office has traditionally enforced such a practice and advised the Director-General in cases which could potentially justify exceptional cooperation or involvement.

Finally, the Office takes part in external activities aimed at ensuring normative coherence and harmonization across the United Nations system. The Legal Counsel participates in meetings of the United Nations Legal Advisers Network, an initiative led by the Legal Counsel of the United Nations that brings together the legal advisers of specialized and related agencies, legal liaison advisers/officers of entities including United Nations offices away from headquarters, funds and programmes, regional commissions and ad hoc tribunals, and field legal officers for United Nations peace operations. The Network is intended to foster coherence in legal approaches across the United Nations system as well as to discuss common concerns and positions with regard to shared legal issues. As such, it provides a unique forum for update, discussion and exchange of experience on legal challenges affecting the United Nations and its agencies, such as matters relating to privileges and immunities, the international responsibility of UN system organizations, reservations to treaties, taxation, or intellectual property rights issues arising from the activities of those organizations. The Legal Network is also one of the official networks of the High-Level Committee on Management of the Chief Executives Board, the framework for administrative coordination across the United Nations system. As such, it may be called to provide unified advice on legal aspects of managerial issues of system-wide relevance.

Informal exchanges may also take place with academic institutions. Members of the Office may be invited to contribute to the drafting of articles or to make presentations at academic events where they can clarify the rules and practice of the Organization on specific topics. This enables the development of fruitful cooperation between the Office's lawyers and external scholars, which greatly contributes to the provision of high-quality and up-to-date legal advice as well as to a better understanding of the status and activities of the Organization. 


\section{iv) Support to institutional integrity}

The Office is involved in a wide range of activities aimed at preserving the Organization's integrity and managing risks. Integrity in the sense intended here has an external as well as an internal dimension. A good example of the external dimension is provided by the large amount of legal work arising in connection with the privileges and immunities of the Organization and its staff. The legal officers are sometimes confronted with difficult situations where the legal protection of the status of the Organization and its staff needs to be balanced with the Organization's operational needs and its obligations to either waive immunities or offer alternative modes of dispute settlement. In such instances, the Office provides advice and assistance on the legal implications entailed by any decision to uphold or waive such privileges and immunities, and is involved in all the phases of the negotiation process with Member States regarding these matters. It also has to advise the Director-General or the Regional Director concerned in a manner that upholds the applicable law and the obligation of the Organization to cooperate with the administration of justice within its member states, while at the same time taking into account the context and particular circumstances of the situation at hand. It is fair to say that, in such cases, the Office's advice reflects policy considerations and an accurate appreciation of the facts beyond the strict confines of the applicable legal instruments.

From an internal perspective of integrity and accountability, the Office regularly cooperates with those departments which are responsible for the conduct of investigations, oversight, evaluation and audits, as well as for the management of compliance, ethics and risk management matters. Legal advice and support was provided also in relation with the development of the WHO Framework of Engagement with Non-State Actors (FENSA) adopted in May 2016 ${ }^{53}$, throughout its negotiation process, and will continue to be

53 WHO, Resolution WHA69.10, Framework of engagement with non-State actors. The Framework is available at the following link: http://www.who.int/about/collaborations/non-stateactors/en/ (last accessed 10 February 2017). 
provided to support the implementation of the Framework. The Framework regulates the interactions of WHO with the four categories of non-state actors with which it typically works - non-governmental organizations, private sector entities, philanthropic foundations and academic institutions - with a view to enabling an effective engagement for the purposes of the Organization while at the same time safeguarding the integrity of its functions and avoiding perceived conflicts of interest.

\section{Internal structure}

It should be recalled at the outset that the Legal Counsel is first and foremost the legal adviser of the Director-General as executive head of WHO as well as of the senior management of the Organization. Given the centralized nature of legal advisory functions within WHO, he or she is also the legal adviser of the Regional Directors and, through them, of the senior management of regional offices. The heads of country offices also often call upon the Office directly for the provision of legal advice and support, for example with regard to questions of privileges and immunities as noted above, or of contractual or tortious responsibility.

The Legal Counsel, as head of the Office, is responsible for the efficient leadership, management and administration of the Office, and external representation at meetings and conferences of a legal nature, as well in judicial or arbitral proceedings. The direct reporting and managerial accountability lines between the Legal Counsel and the Director-General underscores the institutional role played by the Office and its high degree of independence from the Organization's senior management. A specific feature of the Office, as just noted, is its centralized nature in what is a very decentralized institution. This circumstance ensures unity and coherence of legal advice as well as greater institutional integrity at all levels of the organization, thereby serving as a "counterbalance" to the decentralization of organizational functions. The technical nature of the Organization may sometimes pose a challenge to the effectiveness of the advisory function of the Office, WHO being largely staffed by health professionals who 
understandably tend to appreciate matters from a technical, programmatic or operational point of view and may not be familiar with the legal parameters or implications of those matters. In order to effectively overcome such communication challenge, great attention is paid in the Office to the manner in which legal analysis and advice is communicated to colleagues. Clear communication is indeed key to a correct understanding of the risk assessment and management role played by the Office as one of the "guardians" of the institutional integrity of the Organization, especially in those circumstances where advice is given against the proposed decision or activity. At the same time, there is awareness in the Office that a balance needs to be found between such risk assessment and management functions, and the need for the Organization to effectively accomplish its mandate through its technical and operational activities. Potential legal issues and reputational risks are therefore always considered and addressed from a realistic and constructive perspective, taking into account the acceptable level of such risks, and without losing sight of the Organization's objective and programmatic priorities. This tension may become more apparent during public health emergencies, which may understandably justify a higher level of risks acceptability in order to enable the Organization to address effectively and rapidly the situation at stake.

Work is divided across three functional units, i.e .Governing Bodies and Public International Law (GBI), Commercial and Contractual Matters (CCM), and International Administrative Law (IAL). This semi-specialization, which has not been formalized but is a result of practice, mirrors the main areas of legal work generated by the Organization and is intended to address more effectively and efficiently the various legal matters brought to the attention of the Office through a degree of specialization of its staff. The legal officers have a very diverse academic and professional background with fields of specialization ranging from public international law to administrative law, commercial and contractual law, and a fairly balanced representation of both civil law and common law systems. Prior to joining the Office, legal officers usually gained experience in law firms and/or the legal services of national administrations, other international organizations within or outside the UN system or even non-governmental organizations. 
The core function of the GBI unit is to provide legal services to the DirectorGeneral, regional and country offices, WHO units, programmes and intergovernmental bodies on issues related to the structure, mandate and functions of the Organization and its status under international law. More in particular, this unit deals with legal issues arising in connection with meetings of the Health Assembly, the Executive Board, Regional Committees and any other intergovernmental and similar meetings convened by WHO. It is primarily responsible for matters of a constitutional and international legal nature, including those related to WHO normative activities connected with the IHR, the WHO FCTC and its Protocol, the PIP Framework and the participation of WHO in the Codex Alimentarius Commission. ${ }^{54}$ In addition, GBI's work focuses on the protection of the Organization's system of governance, with particular regard to the integrity of the activities of policy-making and standard-setting bodies; the relations of WHO with its Member States and/or other intergovernmental organizations; the status under international law of States, areas, territories and other entities as they affect WHO's activities; the publication of WHO materials with particular regard to terminology and cartographic representation; the relations of WHO with the respective host State of its headquarters and out-posted offices, as well as regional, country and liaison offices and centers, including questions on the privileges and immunities of the Organization and its status under international law.

The core function of the CCM unit is to provide legal services in respect of all aspects of WHO's commercial and contractual matters as well as with regard to the legal aspects of WHO's interactions with the private sector. In particular, this unit deals with legal issues arising in connection with the negotiation, conclusion and implementation of various types of agreements, such as those related to intellectual property rights, licensing

\footnotetext{
${ }^{54}$ The Codex Alimentarius Commission is the principal organ of the Joint FAO/WHO Food Standards Programme, which was set up by the Eleventh Session of the FAO Conference by virtue of resolution 12/61 in 1961 and was subsequently approved by the Sixteenth World Health Assembly by virtue of resolution WHA16.42 in May 1963. For more information on Codex please see http://www.fao.org/fao-who-codexalimentarius/en/ (last accessed 11 February 2017)
} 
and research and development, technical services agreements, agreements for performance of work and contractual services agreements, cash and in-kind donations, information technology, construction and lease and project collaboration. Furthermore, CCM's work focuses on procurement of goods and services, the organization or cosponsorship of meetings with commercial implications (e.g. involving private sector entities among the co-organizers or sponsors or receiving funding from such entities), the use of WHO's name and emblem with commercial implications (e.g. in the context of cooperative activities with private sector entities), most issues arising from the hosting of public-private partnerships, the resolution of disputes of a commercial nature, and the provision of technical assistance to Governments .

The IAL unit provides legal services and advice to WHO's management, including the Office of the Director-General, the Human Resources Department, as well as regional and country offices on specific incidents involving the privileges and immunities of the Organization and its officials, including when the Organization is involved in legal proceedings before national courts. Furthermore, this unit provides legal advice on human resources matters, in particular those related to the interpretation and application of the WHO's Staff Regulations, Rules and any other applicable administrative provisions, the conditions of service for WHO staff, the recruitment, loan and transfer of staff to and by WHO, as well as the representation of WHO before the Administrative Tribunal of the International Labour Organization. Other matters routinely dealt with by this unit are the provision of legal support to oversight, evaluation and investigative functions, the co-sponsorship of meetings not involving commercial issues, the use of WHO name and emblem not involving commercial considerations, the designation and functioning of collaborating centers, the appointment of goodwill ambassadors, legal issues related to non-governmental organizations, and governance issues related to IARC. 


\section{Applicable law}

The applicable law on which the legal officers rely in the performance of their functions mainly consists of the "rules of the Organization" 55 , and relevant sources of international law. Instead, it should be stressed that no recourse is usually made to national legislation except mostly when it is used as a reference for the interpretation of contractual terms. WHO's rules comprise a wide range of sources.

a) The Constitution of the World Health Organization. As mentioned in the first section, the Constitution was adopted on 22 July 1946 and came into force on 7 April. Since its adoption, it has been amended four times in accordance with Article $73{ }^{56} \mathrm{~A}$ direct reliance on the Constitution is not frequent for the work of Office, with the exception of the articles regulating the functions and competences of the governing bodies and the appointment of elected officers, which have been relied on as the basis for advice rendered in the context of the recent reform of WHO's governance.

b) Relevant rules and regulations adopted by the governing bodies or by the Director-General, namely the rules of procedure of the Board, the Health Assembly and the Regional Committees, the Staff Regulations and Rules, the Financial Regulations and Rules, the Regulations for Expert Advisory Panels and Committees, as well as the

55 The expression "rules of the organization" is used in this context as defined in Article 2 b) of the Articles on the Responsibility of International Organizations adopted by the International Law Commission at its sixty-third session in 2011, namely " the constituent instruments, decisions, resolutions and other acts of the international organization adopted in accordance with those instruments, and established practice of the organization". (Draft articles on the responsibility of international organizations, in Yearbook of the International Law Commission, 2011, vol. II, Part Two. The Draft articles were submitted to the General Assembly as a part of the Commission's report covering the work of that session (UN document, A/66/10, para. 87). They were subsequently noted by the UN General Assembly in resolution A/RES/66/100, Responsibility of International Organizations of 2011.

56 See supra note 2 . 
Regulations for Study and Scientific Groups, Collaborating Institutions and Other Mechanisms of Collaboration. ${ }^{57}$

c) Relevant resolutions and decisions of the governing bodies insofar as they decide on procedural or institutional matters, define the terms of reference of intergovernmental or similar processes, or mandate the Secretariat to carry out specific activities that require interpretation. The governing bodies have often clarified the meaning of, or given effect to, constitutional provisions or rules of procedure through the adoption of resolutions or decisions. As previously mentioned, for example, the rights and obligations of Associate Members and other territories under Article 8 and 45 of the Constitution have been laid down in a Health Assembly resolution. ${ }^{58}$ Likewise, it is thanks to a Health Assembly resolution that the nature of persons serving on the Board under Article 24 of the Constitution was eventually clarified. In other cases, the rules of procedure cannot be implemented without taking into account other relevant resolutions and decisions of the governing bodies. This applies, for example, to Rule 52 of the Rules of Procedure of the Board and Rule 108 of the Rules of Procedure of the Health Assembly regarding the nomination and appointment of the Director-General, which must be considered in the context of a number of resolutions and decisions of the Board and the Health Assembly providing the governing principles as well as regulating detailed aspects of the process. Finally, it is worth recalling that the Assembly adopted in May 2016 the above mentioned FENSA. FENSA is the outcome of a prolonged and complex process of reassessment of the interactions that WHO may entertain with non-governmental stakeholders in light of contemporary developments in global health governance and the role of the Organization therein. FENSA in part replaces previous rules and principles on relations with non-governmental organizations and the private sector, and in part is

57 Such rules and regulations are availble in WHO, Basic Documents, 48th ed. World Health Organization, 2014 and also available at: http://apps.who.int/gb/bd/ (last accessed 12 February 2017).

58 WHO, Resolution WHA2.103. 
complementary to other rules and decisions that remain applicable. Its implementation will probably require a deep involvement by the Office both to support the necessary processes to assess specific instances of engagement with non-state actors and to ensure consistency in the interpretation of the various sets of rules.

d) Any policy or administrative issuance adopted by the Director-General in his/her capacity as chief technical and administrative officer under Article 31 of the WHO Constitution, e.g. internal rules on procurement, conflicts of interest and risk management.

e) The established practice of the Organization, as developed over the years, plays a central role in the interpretation and application of the texts mentioned above, as well as for those grey areas where no immediately applicable rules exist. Areas where a substantial amount of relevant practice for the Office has developed are, for example, relations with the private sector and the management of the privileges and immunities of WHO and its staff. The interactions and balance between existing formal rules and the unwritten practice that has developed on top of them are often a delicate question for the Office and require a careful assessment of the specific circumstances as well as of the priorities of the Organization.

f) Normative instruments adopted or endorsed by the governing bodies, in particular the IHR, the WHO FCTC, and the PIP Framework, are of course relevant whenever advice and support is sought from the Office on any of the substantive matters addressed by these instruments. This category includes not only the provisions of the relevant instrument concerned, but also the body of rules and practice that has developed as a result thereof, such as decisions adopted by the Conference of the Parties to the WHO FCTC, or advice given by any of the expert committees convened under the IHR and the PIP Framework. An increasing range of questions for the Office arises from the interactions between WHO's normative instruments and other sources of international law; notable examples are the possible tensions between the WHO FCTC and 
international trade and investment agreements, and those between the PIP Framework and the Convention on Biological Diversity ${ }^{59}$ as well as its Nagoya Protocol on Access to Genetic Resources and the Fair and Equitable Sharing of Benefits Arising from their Utilization to the Convention on Biological Diversity. ${ }^{60}$ These questions may be posed by the governing bodies or be raised within the Secretariat for the purpose of assessing the scope and legal/political implications of its mandate under those instruments ${ }^{61}$.

The rules of the Organization are complemented by other sources of international law that can be categorized as follows:

a) A complex normative framework arises out of the numerous international agreements or non-legally binding arrangements that the Organization has concluded with other intergovernmental organizations, countries and partners on a great variety of matters. Mention can be made, for example, of the cooperation agreements concluded with twelve intergovernmental organizations in accordance with Article 70 of the Constitution $^{62}$, as well as of the international multilateral treaties to which WHO is a party such as the 1986 Conventions on the Early Notification of a Nuclear Accident and

59 Convention on Biological Diversity (Rio de Janeiro, 5 June 1992), 1760 UNTS 79.

60 Nagoya Protocol on Access to Genetic Resources and the Fair and Equitable Sharing of Benefits Arising from their Utilization to the Convention on Biological Diversity (Nagoya, 29 October 2010), Doc.: UNEP/CBD/COP/DEC/X/1.

61 For example, the Executive Board requested the Secretariat to analyze how the implementation of the Nagoya Protocol might affect the sharing of pathogens, and the potential public health implications. An executive summary of the study was presented to the Board at its $140^{\text {th }}$ session in January 2017 (document EB140/15) . The full report is available on the WHO website at http://www.who.int/influenza/pip/2016review/NagoyaStudyAdvanceCopy_full.pdf?ua=1 (last accessed 11 February 2017).

62 Under this provision, formal agreements entered into with the United Nations and other international organizations are subject to approval by a two thirds majority of the Health Assembly, while less formal agreements do not need the Assembly's approval. 
on Assistance in the Case of a Nuclear Accident or Radiological Emergency, respectively. ${ }^{63}$

b) Additionally, the Organization is subject to relevant rules of international customary law as applicable in light of its status and functions as an international organization endowed with separate legal personality under international law. In this respect, the law of treaties is particularly relevant. Accordingly, the Office relies on the relevant Vienna Convention and the International Law Commission's Articles on the Responsibility of International Organizations, but also strives to assess their applicability in the light of available practice.

c) The Organization is of course bound by any judicial or arbitral decision that may be rendered in relation to a case to which it is a party.

d) Finally, there is a clear effort to take into account and implement within WHO, to the maximum extent possible, relevant UN policies and practices in order to ensure consistency across the UN system. WHO followsrelevant decisions and determinations reached by the UN's intergovernmental bodies, in particular the General Assembly and the Security Council. This applies, in particular, to countries, areas and territories whose status is disputed under international law. By way of example, with regard to the status of Kosovo, WHO follows the United Nations' position as reflected in Security Council resolution 1244 (1999) and the practice resulting therefrom regarding participation of Kosovo in WHO meetings as well as references to Kosovo in WHO documents and maps. At the same time, decisions taken by WHO’s governing bodies may at times prevail over corresponding UN's decisions depending on the particular circumstances. Thus, while Palestine has been admitted as a Non-member observer State by the UN General

63 Convention on Early Notification of a Nuclear Accident (Vienna, 26 September 1986) 1439 UNTS 276 ; and Convention on Assistance in the Case of a Nuclear Accident or Radiological Emergency (Vienna, 26 September 1986) 1457 UNTS 133. 
Assembly in $2012^{64}$, it participates in the Health Assembly and Executive Board as an observer (rather than a non-member observer state) in accordance with previous resolutions of the Health Assembly that have not been overridden by the General Assembly's decision. ${ }^{65}$ The rights of participation of Palestine, in particular, are spelled out in resolution WHA53.13 of May $2000^{66}$, which however limits itself to conferring upon Palestine, in its capacity as an observer, the rights and privileges described in resolution 52/250 of the UN General Assembly, whose text is reproduced in an annex. The practice of the Health Assembly differs from that of the General Assembly in several respects, and this has required some careful elaboration and adaptation on the part of the Office when advising on the implementation of resolution WHA53.13 and more generally on the status of Palestine within WHO.

\section{The Office's role in the development of international law}

Assessing the role of the Office in the development and implementation of the rule of law, human rights, international law and the law of international organizations is a challenging task. As far as the advancement of the rule of law at national level is concerned, the Office's direct contribution seems to be overall limited. The Office, for example, is generally not responsible for developing model laws or providing advice on domestic legislation in the area of health. Additionally, since the creation of the Organization, there has been little focus by its Member States on the Health Assembly's

64 Resolution A/RES/67/19 on the Status of Palestine in the United Nations, adopted by the General Assembly on 29 November 2012. The UN General Assembly, inter alia, decided "to accord to Palestine non-member observer State status in the United Nations, without prejudice to the acquired rights, privileges and role of the Palestine Liberation Organization in the United Nations as the representative of the Palestinian people, in accordance with the relevant resolutions and practice.”.

65 Palestine has also been admitted as a Member in the WHO Regional Committee for the Eastern Mediterranean.

66 See supra note 13. 
authority to adopt legally binding instruments that can shape and guide the development of national legislation as well as of rule of law principles. Unlikeother intergovernmental organizations such as FAO, ILO and WIPO, the Organization has predominantly been active in the setting of non-binding standards both as normative and policy prescriptions for its member states and as tools for its work rather than in promoting the conclusion of legally binding instruments under Articles 19 and 21 of the WHO Constitution. As mentioned above, only one international treaty and two sets of regulations have been adopted by the Health Assembly in almost seventy years of WHO's life. The majority of health challenges has been and is still being addressed through soft law instruments such as codes, strategies, plans of action and guidelines. Against this context, the Office has been predominantly called upon to provide advice on procedural and institutional issues in connection with the decision-making processes of the governing bodies and the activities undertaken by the Secretariat in order to ensure compliance with applicable rules and regulations, rather than being involved in the development, negotiation and interpretation of international legally binding instruments. This consideration, of course, is without prejudice to the impact that even non-binding standards may have on the development and harmonization of national regulations on health-related issues or on the development of public international law. Many countries, for example, automatically include medicines contained in WHO's Essential Medicines List in national lists for public procurement or health insurance coverage. In addition, there are situations where the Office is called upon to provide advice on the interpretation of certain provision of WHO's normative instruments, thereby assisting Member States in discharging their international obligations or commitments under these instruments.

A similar observation can be made regarding the role of the Office vis-à-vis international human rights law, which reflects WHO's corporate position. Although the enjoyment of the highest attainable standard of health is recognized as one of the fundamental rights of every human being in the Preamble of the Constitution, there has been historically a certain caution on the part of both Member States and the Secretariat to address health issues deliberately from a human rights perspective. WHO Member 
States, for example, have not yet discussed a possible policy framework for WHO on health and human rights. The Organization nonetheless collaborates with human rights monitoring bodies through the provision of technical and evidence-based information on health issues to assist them in the assessment of national reports. Furthermore, a dedicated team has been established within the Secretariat to oversee the mainstreaming of gender, equity and human rights considerations into WHO’s programmes and policies, with specific efforts currently underway to integrate a human rights based approach into WHO's programming. ${ }^{67}$ The Office has also provided advice on the implications of human rights law and practice with regard to sensitive topics dealt by the Organization, e.g. with regard to reproductive health and abortion.

As far as the law of international organizations is concerned, instead, the Office contributes to the development of a large amount of practice in a wide range of areas, in particular the law of treaties involving international organizations, the procedure of international conferences, the privileges and immunities of the Organization and its staff, the principles applicable to administrative justice, and issues pertaining to the international responsibility of the Organization. The Office regularly contributes to the UN Juridical Yearbook prepared yearly by the United Nations Office of Legal Affairs and has actively contributed to various United Nations-led exercises aimed at codifying or progressively developing international law, such as during the discussions that have led to the adoption by the International Law Commission of the Articles on the Responsibility of International Organizations as well as the Draft articles on the protection of persons in the event of disaster ${ }^{68}$ in light of the impacts that both texts will have on the Organization's work. Not less important is the large body of soft law produced by the

67 In particular through a Roadmap for action, 2014-2019, which describes how the integration of equity, human rights, gender and social determinants will be rolled out, including strategic milestones The Roadmap is available at http://who.int/gender-equity-rights/about/webroadmap.pdf(last accessed 11 February 2017).

68 Draft articles on the protection of persons in the event of disasters 2016, adopted by the International Law Commission at its Sixty-eighth session, in 2016, and submitted to the UN General Assembly as a part of the Commission's report covering the work of that session (document A/71/10), paragraph 48. 
governing bodies and the Secretariat in light of the impact that such standards may have on the interpretation by states of their obligations under international law. For example, the temporary recommendations issued by the Director-General under the IHR in the context of public health emergencies of international concern, based on the advice of the Emergency Committee, may lead states to limit the exercise of certain liberties and rights of individuals or to impose restrictions on international trade, and therefore impact the interpretation and implementation by States of their corresponding international obligations. The Office's involvement at the different stages of drafting, deliberation, implementation and follow-up of such body of law, through the provision of advice on procedural and substantive matters, should therefore not be underestimated.

Finally, the role of the Office of the Legal Counsel has increased in the course of time in terms of the range of its functions and the legal issues that it faces. The reasons behind this phenomenon seem to be threefold. First, the allocation of responsibilities within the Secretariat has occasionally led to the Office's involvement in matters relating to the policy-making activities of the Organization. Secondly, the expansion of the Office's role mirrors a cultural change linked to the growing politicization of global health in the international arena. The intersections between public health issues and other policy and legal domains such as international trade and intellectual property law, have become increasingly apparent in the last two decades. This has triggered not only a strengthened cooperation and coordination between WHO and other international organizations such as WIPO and WTO, but also a shift in the nature of the discussions within WHO’s governing bodies towards, notably, the impact of international economic law on the protection and promotion of public health. In turn, the need for legal advice has significantly increased and the staff of the Office has progressively become conversant with rules of international law that did not previously form part of its "working tools". Because of these developments, the internal perception of the Office has improved in the course of time and led to a greater willingness on the part of technical staff to regularly involve legal officers at all stages of the decision-making processes in order to identify and avoid, from the outset, potential legal, political and reputational 
risks, rather than only "ex post" to find practicable solutions to overcome already existing legal issues.

Thirdly, the decision-making process followed by the governing bodies of the Organization has undergone a gradual but notable change since the late 1990s. Whereas intergovernmental negotiations were previously mostly confined to the regular sessions of the governing bodies, Member States have been increasingly willing to pursue negotiations and discussions on specific health topics in the framework of protracted intergovernmental processes, which often require input from the Office both on substantive and procedural matters. Regardless of the terms used to describe such mechanisms - for example, "intergovernmental working groups", "open-ended meetings" and "working groups of Member States" - they all receive their mandate from the Health Assembly or the Executive Board, to which they must report regularly and which take the final decisions on the outcome of their work. Intergovernmental processes of this kind were set up - and some of them are still ongoing - to tackle a wide range of matters, such as substandard and falsified medical products ${ }^{69}$, and questions relating to the functioning of the Organization, such as its relationship with non-State actors and the reform of its governance. The proliferation of intergovernmental negotiations and processes has increased the workload of the Office and led to an internal division of labour among legal officers to ensure continuity and expertise in supporting Member States and responsible technical units within the Secretariat. ${ }^{70}$

69 A Member State mechanism on Substandard/spurious/falsely-labelled/falsified/counterfeit medical products (SSFFC) has been established by the Sixty-fifth Health Assembly for international collaboration of Member States in this area. Relevant documentation can be accessed at http://apps.who.int/gb/ssffc/ (last accessed 26 August 2016). To note that the Executive Board at its $140^{\text {th }}$ session in January 2017 recommended that the Seventieth World Health Assembly replace the term "substandard/spurious/ falsely-labelled/falsified/counterfeit medical products" with "substandard and falsified medical products" as the term to be used in the name of the Member State mechanism and in all future documentation on the subject of medical products of this type (decision EB140(6)).

70 On the process that ultimately led to the adoption, by the Health Assembly in May 2016, of the Framework of Engagement with non-State actors see supra note 51. Governance reform has been one of the three aspects of WHO reform since 2011. The negotiations conducted in the framework of a Member States consultative process, followed by an open-ended 


\section{Conclusions}

This overview of the role of the Office within the structural and functional context of WHO is indicative of the developments that legal advisory functions in international organizations have been undergoing in recent decades. Such developments reflect and are the consequence of corresponding changes within the functional areas covered by the mandate of those organizations as well as of the overall perception by states of their role and usefulness. Global health, as noted above, is characterized by an increasing politicization deriving from the tension between public health principles on the one hand, and the impact of diverse areas of international law and politics such as on economic integration and development, international security, environmental concerns and the emergence of novel forms of international governance including private actors. Such politicization has penetrated WHO's agenda and led to shifting demands and expectations by member states on the Secretariat. The Office has followed and to a certain extent anticipated such a trajectory; while many services provided by the Office still fall within the typical functions of the inside counsel of a large institution, the demands placed on it by WHO’s governing bodies and senior management transcend its traditional and narrower in-house role and have led to a better knowledge and appreciation of a broad range of international law rules and processes. This has, in turn, arguably increased the impact of the Office on the normative developments and international deliberations that shape, directly and indirectly, the development of public international law.

intergovernmental meeting, throughout 2015 and 2016 have led to the adoption by the Health Assembly, in decision WHA69(8) of May 2016, of a set of agreed actions to improve the methods of work of the governing bodies as well as alignment across the three levels of the Organization, including with regard to regional processes for the nomination of the Regional Director. More information on the intergovernmental processes mentioned above can be found at http://apps.who.int/gb/gr/ . 